\title{
Clinical Article Orthopaedics
}

\section{CADAVERIC STUDY OF MORPHOMETRIC ANALYSIS OF ANTERIOR CRUCIATE LIGAMENT AND ITS SIGNIFICANCE}

\section{A. D. Sampath Kumar ${ }^{1}$, M.R.Manimekalai ${ }^{2}$}

1 - Professor, Department Of Orthopaedics, Government Mohan Kumaramangalam Medical College Salem Tamilnadu

2 - Assistant Professor, Department Of Anatomy, Government Mohan Kumaramangalam Medical College Salem Tamilnadu
Corresponding Author

Dr. M.R.Manimekalai M.S. (Anatomy)., Assistant Professor, Department Of Anatomy, Government Mohan Kumaramangalam Medical College Salem Tamil Nadu Dr. MGR Medical University

21/1, Ellappa Chetty Colony, Anna Salai, Koneripatty, Rasipuram, Namakkal, Tamilnadu-637408 Ph: 9443685800

\begin{abstract}
Introduction: To determine the accurate morphometric data pertaining to the Anterior cruciate ligaments in relation to the south Indian population.
\end{abstract}

Aims And Objectives: To analyse the following parameters of Anterior cruciate ligament of the knee joint. Length and Width of Anterior Cruciate Ligaments as well as the extent of their variations.

Methods \& Materials: The study was carried out in the Department of Anatomy of Govt. Mohan Kumaramangalam Medical College Hospital, Salem. Subjects having no obvious macroscopic deformities of their knee joints and ages ranging between 30 years to 60 years of both sexes were only chosen. 30 knee joints belonging to 15 cadavers matching the above criteria were dissected for the study.

Result \& Analysis: The mean length of the ACL of left side was recorded to be $28.06 \mathrm{~mm}$ and the mean width of the $A C L$ in its middle third was recorded to be $10.33 \mathrm{~mm}$ in the Left side. The mean length of the ACL for the right side was found to be $28.53 \mathrm{~mm}$ and mean width of the ACL in its middle third on the right side was found to be $10.23 \mathrm{~mm}$.

Conclusion: This study will provide valuable information related to the length and width of the Anterior cruciate ligament in South Indian population for cruciate ligament reconstruction.
Keywords: Morphometry, cruciate ligaments, knee joint 


\section{Introduction}

Cruciate ligaments are very strong ligaments of knee joint. There are two cruciate ligaments, one being Anterior (ACL) and the other being Posterior (PCL) in par with their attachments to the tibia . Cruciate ligaments play an equally important role in providing stability to the knee joint. The ACL of knee is the most commonly injured ligament, representing about $60 \%$ of all knee injuries. ACL injuries show long term effects on knee joint such as degenerative joint diseases like secondary osteoarthritis. So, reconstruction of ACL is essential in injured cases. For reconstruction surgery, it is essential to know the detailed anatomy and morphometric measurements of ACL and weather to use it as single bundle or double bundle reconstruction. Henceforth for the surgical repair of cruciate ligaments it is mandatory that surgeons should have detailed anatomical knowledge about various morphometric data of anterior cruciate ligaments, which will guide them in determining the appropriate size of the allograft to be utilized in the procedure of such reconstruction.

\section{Aims \&Objectives}

1. To study the following parameters of Anterior Cruciate Ligaments of the knee joint -

a) Length of Anterior Cruciate Ligaments.

b) Width of Anterior Cruciate Ligaments at their middle $3 \mathrm{rd}$.

2. To document the extent of variation in the above parameters.

\section{Materials \&Methods}

The study was carried out in the Department of Anatomy of Government mohankumaramangalam medical college during a period of two year. Subjects having no obvious macroscopic deformities of their knee joints and ages ranging between 30 years to 60 years of both sexes were only chosen. 30 knee joints belonging to 15 cadavers matching the above criteria were dissected for the study. Knee joints of both sides were dissected .After dissecting the skin, soft tissues and muscles, the menisci were approached anteriorly by a longitudinal incision on each side of the joint capsule, cutting the patellar ligament transversely. The anterior cruciate ligament (ACL) and the posterior cruciate ligament (PCL) were dissected after removing the intraarticular fat and other soft tissues,so that their femoral as well as tibial attachments can be clearly denoted. The ACL was measured for its length \& width (at middle 3rd) from the anterior aspect of the joint. The above was done by means of a digital Vernier Calliper .

\section{Results \& Analysis}

Amongst the 30 cadaveric knee joints dissected (in 15 cadavers) for the purpose of this present study, 19 were males and 11 were females. The mean age of the cadavers were found

to be 51 with a Standard Deviation ( SD ) of 6.63. The maximum age was recorded to be $60 \mathrm{yrs}$. and minimum to be 40 yrs. In the present study, the mean length of the ACL of left side was recorded to be $28.06 \mathrm{~mm}$ with SD of 1.571 and the mean width of the ACL in its middle third was recorded to be $10.33 \mathrm{~mm}$ with SD of 0.872 .

The mean length of the ACL for the right side was found to be $28.53 \mathrm{~mm}$ with SD of 1.691 and mean width of the ACL in its middle third on the right side was found to be $10.23 \mathrm{~mm}$ with SD of 0.651 .

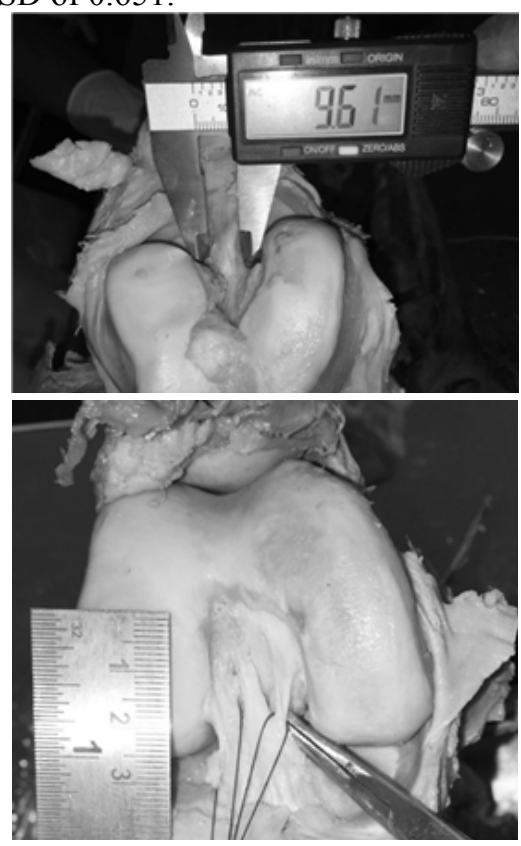

Table 1. Descriptive statistics of numerical variables -left side

\begin{tabular}{|l|c|c|c|c|c|c|}
\hline \multicolumn{1}{|c|}{ S.No } & Min & Max & Mean & Median & 95\% CI & Std. Dev \\
\hline Age (yrs) & 40 & 60 & 51 & 55 & & 6.633 \\
\hline $\begin{array}{l}\text { ACL } \\
\text { length } \\
\text { (mm) }\end{array}$ & 26.5 & 31 & 28.06 & 28 & $26.49-29.63$ & 1.57 \\
\hline $\begin{array}{l}\text { ACL } \\
\text { width } \\
\text { (mm) }\end{array}$ & 9 & 12 & 10.33 & 10.5 & $\begin{array}{c}9.46- \\
11.2\end{array}$ & 0.87 \\
\hline
\end{tabular}

Table 2. Descriptive statistics of numerical variables -Right side

\begin{tabular}{|l|c|c|c|c|c|c|}
\hline \multicolumn{1}{|c|}{ S.No } & Min & Max & Mean & Median & 95\% CI & Std. Dev \\
\hline Age (yrs) & 40 & 60 & 51 & 55 & & 6.633 \\
\hline $\begin{array}{l}\text { ACL } \\
\text { length } \\
\text { (mm) }\end{array}$ & 26 & 31.5 & 28.53 & 28.5 & $26.84-30.22$ & 1.69 \\
\hline $\begin{array}{l}\text { ACL width } \\
\text { (mm) }\end{array}$ & 9.5 & 11.5 & 10.23 & 10 & $9.57-10.88$ & 0.651 \\
\hline
\end{tabular}




\section{Discussion}

In standard anatomical textbooks, the average length and width of the $\mathrm{ACL}$ is mentioned to be $38 \mathrm{~mm}$ and $11 \mathrm{~mm}$ respectively. Odensten et al ,recorded the average length of the ACL in 33 cadaveric knee joints to be $31 \mathrm{~mm}$. Whereas, Gillquist et length was found to be $28.53 \mathrm{~mm}$ in

\begin{tabular}{|l|c|c|c|}
\hline S.NO & Present Study & Odensten et.al & Gilquist et.al \\
\hline ACL & $28.06 \mathrm{~mm}$ (Left) & $31 \mathrm{~mm}$ & $32 \mathrm{~mm}$ \\
Length & $28.53 \mathrm{~mm}$ (Right) & 3 & \\
\hline
\end{tabular}

Yelicherla et al in their study regarding the cruciate ligaments of the knee joints in cadavers, recorded the mean length and width of the ACL considerably greater in males when compared to that of the female. Unlike this present study, the study done by Yelicherla et al showed the mean length of the ACL irrespective of the side, to be $43.5 \mathrm{~mm}$ in males and $41.9 \mathrm{~mm}$ in females. The mean width of the ACL in the same study was recorded to be $12.1 \mathrm{~mm}$ in case of male cadavers and $11.0 \mathrm{~mm}$ in case of the female cadavers. Thus, both these recorded values were significantly higher when compared to the same for the present study which is $10.33 \mathrm{~mm}$ with standard deviation of 0.651 .

\begin{tabular}{|l|c|c|}
\hline \multicolumn{1}{|c|}{ S. No } & $\begin{array}{c}\text { Present } \\
\text { study }\end{array}$ & $\begin{array}{c}\text { Yelicherla } \\
\text { et. al }\end{array}$ \\
\hline Mean & & $12.1 \mathrm{~mm}$ \\
width of & 10.28 & $(\mathrm{M})$ \\
M/3rd & $\mathrm{mm}$ & $11.0 \mathrm{~mm}$ \\
ACL & & $(\mathrm{F})$ \\
\hline
\end{tabular}

Present study has limitations; we are not analyzing bundles if cruciate ligament separately in formalin fixed cadavers.

\section{Conclusion}

The present study will contribute to the literature regarding the morphometry of the cruciate ligaments of the knee joint in South Indian population. This will provide al,measured the length of the ACL in cadavers to be $32 \mathrm{~mm}$. In our study the right side and $28.03 \mathrm{~mm}$ in left side with standard deviation of $1.57 \& 1.69$ respectively. This findings compared to other studies is less in South Indian population.

\section{References}

1. Amis AA, Jakob RP. Anterior cruciate ligament graft positioning, tensioning and twisting. Knee Surg Sports Traumatol Arthrosc 1998; 6 ( suppl 1):S2-S12.

2. Beynnon BD, Johnson RJ, Fleming $\mathrm{BC}$, et al. Anterior cruciate ligament replacement: Comparison of bone patellar tendon-bone grafts with two-strand hamstring grafts. A prospective, randomized study. J Bone Joint Surg Am 2002; 84: 1503-1513.

3. Fanelli GC, Edson CJ. Posterior cruciate ligament injuries in trauma patients: part II. Arthroscopy 1995;11:526-529

4. Fanelli, G.C., Feldmann, D.D. The dislocated/multiple ligament injured knee. Oper Tech Orthop. 1999;9:298-308.

5. Siebold R, Ellert T, Metz S, Metz J. Femoral insertions of the anteromedial and posterolateral bundles of the anterior cruciate ligament : Morphometry and arthroscopic orientation models for double-bundle bone tunnel placement A cadaver study. Arthroscopy $2008 ; 24: 585-592$.

6. Odensten M, Gillquist J. Functional anatomy of the anterior cruciate ligament and a rationale for reconstruction . J Bone Joint Surg (Am) 1985; 67(2): 2

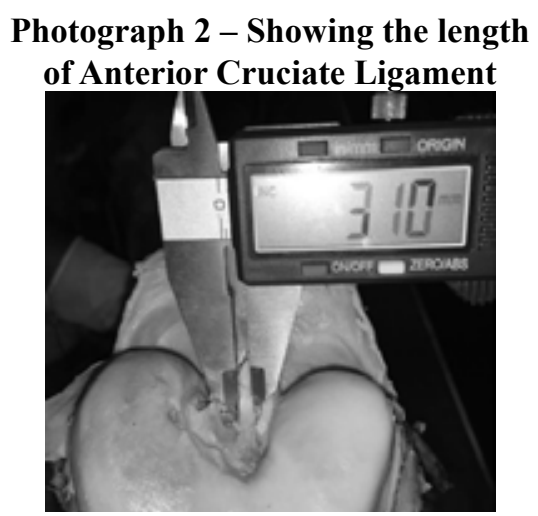

7. Standring $\mathrm{S}$. The anatomical basis of clinical practice .In: Standing $\mathrm{S}$, editor-in-chief. Gray's Anatomy. 39th ed. London: Elsevier Limited, 2006; 1476-1487.

8. Amis AA, Gupte CM, Bull AM, Edwards A. Anatomy of the posterior cruciate ligament and the meniscofemoral ligaments. Knee Surg Sports Traumatol Arthrosc . 2006 ;14(3):257-63

9. Odensten M, Gillquist J. Func- 
tional anatomy of the anterior cruciate ligament and a rationale for reconstruction. J Bone Joint Surg (Am) 1985; 67(2): 257-62.

10. Gillquist J. Drill hole reproducibility in ACL reconstruction. Sports Med Arthrosc 1996; 4:3429.

11. Yelicherla A.K.R.,Gabje U.,Singh Brijraj,; Asian Pac. J. Health Sci., 2014; 1(3): 285-291. 